\title{
Preliminary Assessment of Resistance Among U.S. Wheat Cultivars to the Triticum Pathotype of Magnaporthe oryzae
}

Christian D. Cruz, William W. Bockus, James P. Stack, Xiaoyan Tang, and Barbara Valent, Department of Plant Pathology Kansas State University, Manhattan, KS 66506; and Kerry F. Pedley and Gary L. Peterson, USDA-ARS Foreign Disease-Weed Science Research Unit, Fort Detrick, MD 21702

\begin{abstract}
Cruz, C. D., Bockus, W. W., Stack, J. P., Tang, X., Valent, B., Pedley, K. F., and Peterson, G. L. 2012. Preliminary assessment of resistance among U.S. wheat cultivars to the Triticum pathotype of Magnaporthe oryzae. Plant Dis. 96:1501-1505.

Magnaporthe oryzae is the causal agent of blast disease on several graminaceous plants. The $M$. oryzae population causing wheat blast has not been officially reported outside South America. Wheat production in the United States is at risk to this pathogen if it is introduced and established. Proactive testing of U.S. wheat cultivars for their reaction to blast and identification of resistance resources is crucial due to the national and global importance of the U.S. wheat industry. In this preliminary study, the phenotypic reaction of 85 U.S. wheat cultivars to M. oryzae (Triticum pathotype) was determined. Although there was a

plant stages, only $57 \%$ of the head reaction was explained by the seedling reaction. Because of the importance of disease development at the head stage in the field, assessment of all 85 cultivars occurred at the head stage. Among cultivars tested, a continuum in severity to head blast was observed; cultivars Everest and Karl 92 were highly susceptible with more than $90 \%$ disease severity, while cultivars Postrock, JackPot, Overley, Jagalene, Jagger, and Santa Fe showed less than 3\% infection. No evidence of the presence of physiological races among isolates T-7, T-12, T-22, and T-25 was found.
\end{abstract} significant correlation in the reaction to blast at the seedling and adult
Magnaporthe oryzae B.C. Couch \& L.M. Kohn (anamorph, Pyricularia oryzae) is a fungal pathogen with a high degree of host specificity (5). It is the causal agent of blast disease on several graminaceous plants, including wheat (Triticum aestivum L.). Blast disease was reported for the first time on wheat in 1985 (14) in the Paraná State of Brazil, where it had caused severe damage to the local wheat cultivars. Although the disease occurs sporadically, it is now considered a major threat to wheat production in Brazil (19). Since its first report in Paraná, the disease has been detected in the important wheat-producing regions of the country $(7,10,11,13,17)$. In 1996, it was reported for the first time in the Santa Cruz Department of Bolivia (2). In 2002, it was reported in the Itapúa and Alto Paraná Departments of Paraguay (24). Finally, in 2007, it was reported for the first time in the province of Formosa, northeastern Argentina (4). It has been suggested that wheat blast populations possess a high degree of variation among isolates $(22,23)$. Sexual and/or parasexual recombination may be responsible for the genetic variation observed in this pathogen $(3,20)$.

The Triticum pathotype of $M$. oryzae can reduce both yield and quality $(8,19)$. Grains from blast-infected heads from highly susceptible cultivars are usually small, wrinkled, deformed, and have low test weight (8). The highest yield losses occur when head infections start during flowering or early grain formation (8). Reported yield losses in Brazil on susceptible cultivars vary from 10.5 up to $100 \%(10,12,15)$. An analogous head disease with similar symptoms, Fusarium head blight, has had similar impacts on wheat production in the United States (16). Wheat blast may have similar epidemiology to Fusarium head blight because it also affects the heads soon after emergence. Therefore, the search for genetic resistance to wheat blast in the United States is important.

In South America, there has been an intense search for sources of resistance to wheat blast since it was discovered in Brazil

Corresponding author: Christian D. Cruz, E-mail: ccruz@ksu.edu

Accepted for publication 18 April 2012.

http://dx.doi.org/10.1094/PDIS-11-11-0944-RE

(C) 2012 The American Phytopathological Society
$(1,9,13,18,21,23)$. However, no sources of durable resistance have been found (23). Urashima et al. (23) tested 20 commercial wheat cultivars for resistance to 72 isolates of the Triticum pathotype of $M$. oryzae. Although BR18 had the best performance, no promising resistant cultivar was identified in their study. Prestes et al. (18) evaluated 100 Brazilian wheat genotypes for resistance to head blast. Eighteen genotypes among commercial cultivars and advanced breeding lines showed moderate resistance; however, no genotype with complete resistance was reported. Cruz et al. (6) tested 50 Brazilian commercial cultivars and 20 synthetic wheat genotypes from crosses between Triticum durum and Aegilops tauschii for resistance to 18 isolates of the Triticum pathotype of M. oryzae. In general, synthetic wheat genotypes showed less area affected at the adult plant stage and were considered promising sources of resistance to wheat blast.

Since no resistant cultivars have been found within the local South American wheat population, where the disease has been particularly severe, cultivars grown in other areas and wild relative species should be tested to identify all possible sources of resistance. The availability of wheat cultivars with genetic resistance to $M$. oryzae would provide an advantage for U.S. wheat producers to strengthen preparedness in the event of a wheat blast outbreak. Phenotyping of U.S. cultivars for their reaction to wheat blast pathogens and identification of resistance resources is crucial due to the national and global importance of the U.S. wheat industry. In this study, we provide a phenotypic characterization of 85 U.S. hard winter wheat cultivars for reaction to head blast.

\section{Materials and Methods}

Phenotyping of cultivars was performed in a biosecurity level-3 laboratory at the Biosecurity Research Institute (BRI) on the campus of Kansas State University in Manhattan. This laboratory is in a facility designed to provide a safe and secure location to study exotic and high-consequence pathogens. Biocontainment enhancements include individual security PIN code access control, hallway security cameras, interlocked anteroom doors, centralized shower out block, HEPA filtration of exhaust air, gastight dampers to isolate the laboratory, liquid effluent decontamination, and stand-by power generation. Two plant growth chambers (Conviron, Winnipeg, Canada) were used to provide precise control of temperature, 
photoperiod, and light intensity. USDA Animal and Plant Health Inspection Service inspected and approved the laboratory, and a permit (No. P526P-09-01917) was granted to work with M. oryzae in this facility.

Wheat cultivars were grown and vernalized at the KSU Department of Plant Pathology facilities (outside of containment) and then transferred into containment prior to inoculation. Seeds were germinated in $2.5 \times 13 \mathrm{~cm}$ plastic tubes (Stuewe \& Sons, Tangent, $\mathrm{OR})$ and grown for 2 weeks in a greenhouse $\left(25: 15^{\circ} \mathrm{C}\right.$, day:night and 14:10 h, light:dark). The seedlings were vernalized during 8 weeks in a cold room $\left(4^{\circ} \mathrm{C}\right.$ and 9:15 h, light:dark $)$ and then transplanted and grown in the greenhouse to the heading stage in 15cm-diameter pots. They started producing heads approximately 6 to 7 weeks after transplanting.

The monosporic Brazilian M. oryzae (Triticum pathotype) isolate T-25 was used for evaluating several hard winter wheat cultivars adapted to the Great Plains. This isolate was originally collected by Seiji Igarashi from the cultivar Tapejara at São Jorge do Ivaí, Paraná, in January 1988. Inoculum was produced from cultures grown on V8 agar ( $150 \mathrm{ml}$ of $\mathrm{V} 8$ juice, $3 \mathrm{~g}$ of $\mathrm{CaCO}_{3}$, and 15 $\mathrm{g}$ of agar in 1 liter of deionized water) and incubated at 23 to $25^{\circ} \mathrm{C}$ under continuous fluorescent illumination $\left(25 \mu \mathrm{moles} / \mathrm{m}^{2} / \mathrm{s}\right)$. Fiveto seven-day-old colonies were flooded with sterile deionized water containing $0.42 \%$ gelatin and $0.01 \%$ Tween 20 and gently scraped with a disposable inoculation loop to dislodge conidia from conidiophores. The spore suspension was then filtered through two layers of cheesecloth and adjusted to $2 \times 10^{4}$ co$\mathrm{nidia} / \mathrm{ml}$ in a solution of deionized water, gelatin, and Tween 20 .

Disease phenotyping consisted of eight completely randomized design experiments, with three replications (pots) per cultivar, 5 to 10 heads per replicate, and a maximum of 20 cultivars per experiment. The highly susceptible cultivar Everest served as a control in all experiments. Heads were tagged and sprayed $(1.2 \mathrm{ml} / \mathrm{head}$ with $2 \times 10^{4}$ spores $/ \mathrm{ml}$ ) within 3 days of full head emergence (beginning of anthesis) and then individually covered with a black, $7.5 \times 13$ $\mathrm{cm}$ bag with a zipper closure (Uline, Coppell, TX). The bag had been moistened with water on the inside to maintain high humidity conditions. Bags were removed $48 \mathrm{~h}$ after inoculation, and plants remained inside the growth chamber until 14 days after inoculation when heads were rated for disease symptoms. For each wheat head, the number of diseased spikelets was determined and expressed as a percentage of the total number of spikelets on that head: disease $=($ number of diseased spikelets/total spikelets $) \times$ 100. In order to comply with biocontainment regulations, infected plants were properly bagged and autoclaved prior to disposal.

The reproducibility of disease phenotyping was evaluated in two independent experiments by comparing visual assessments of the percentage of wheat spikelets affected by blast. Twelve winter

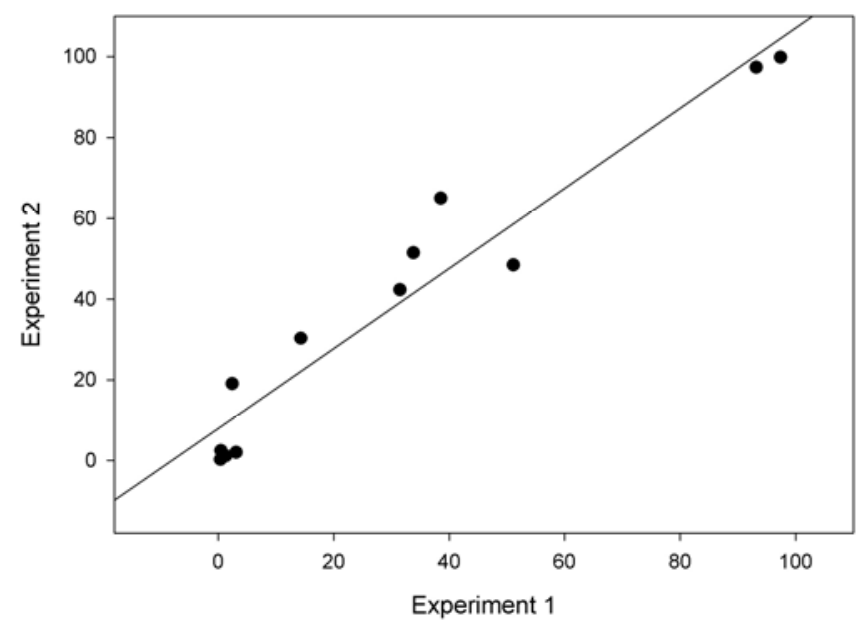

Fig. 1. Wheat blast severity values (percent affected spikelets) for 12 artificially inoculated cultivars from two independent experiments. Pearson's correlation between experiments was $r=0.96, N=12, P<0.0001$. wheat cultivars (Jagalene, JackPot, Tomahawk, Postrock, Aspen, Santa Fe, Hitch, Fuller, TAM 107, Armour, Karl 92, and Everest) that showed a continuum of reaction to wheat blast isolate T-25 were used in each of these experiments.

Disease phenotype assessments at the seedling stage were compared with disease phenotype assessments at the head stage on the same cultivars to determine any correlation between seedling and adult plant resistance. The 12 cultivars mentioned above, showing a continuum of reaction to isolate T-25, were used. Seedling disease phenotyping consisted of a randomized complete block design with four replications (blocks), conducted two times. Seedlings were grown in soil in flats in the greenhouse to the three-leaf stage and then moved to the biocontainment laboratory for inoculations. Seedlings in each flat were sprayed with $25 \mathrm{ml}$ of a spore suspension $\left(2 \times 10^{4}\right.$ spores $\left./ \mathrm{ml}\right)$ and covered with a black 170-liter garbage bag to maintain high humidity. Bags were removed $48 \mathrm{~h}$ after inoculation. Seedlings remained inside the growth chamber in containment until 7 days after inoculation, when leaves were rated for disease symptoms. Disease ratings consisted of visual assessments of the percentage of the second leaf affected by wheat blast, and mean severity scores were based upon the reaction of 10 plants per replication.

Differences in pathogenicity among four Triticum isolates of $M$. oryzae (T-7, T-12, T-22, and T-25) were determined. Phenotypes obtained with the first three isolates were compared among them-

Table 1. Disease severity and resistance rating to wheat blast for 85 U.S. hard winter wheat cultivars ${ }^{\mathrm{a}}$

\begin{tabular}{|c|c|c|}
\hline No. & Cultivar & Disease severity ${ }^{\mathbf{b}}$ \\
\hline 1 & RonL & 0.05 \\
\hline 2 & CO050337-2 & 0.82 \\
\hline 3 & GA-981621-5E34 & 0.93 \\
\hline 4 & Santa Fe & 1.00 \\
\hline 5 & 2609 & 1.12 \\
\hline 6 & Jagger & 1.26 \\
\hline 7 & Jagalene & 1.29 \\
\hline 8 & SY Gold & 1.42 \\
\hline 9 & Overland & 1.46 \\
\hline 10 & Overley & 1.46 \\
\hline 11 & Protection CL & 1.61 \\
\hline 12 & HV9W03-539R & 1.66 \\
\hline 13 & Jackpot & 1.68 \\
\hline 14 & Shocker & 2.00 \\
\hline 15 & CO050175-1 & 2.29 \\
\hline 16 & KS05HW136-3 & 2.39 \\
\hline 17 & Postrock & 2.44 \\
\hline 18 & Danby & 2.84 \\
\hline 19 & $\mathrm{CO} 050173$ & 3.61 \\
\hline 20 & Hawken & 3.81 \\
\hline 21 & NuDakota & 4.23 \\
\hline 22 & Greer & 4.84 \\
\hline 23 & CJ & 4.88 \\
\hline 24 & GA99-1371-6E12 & 5.09 \\
\hline 25 & WB-Stout & 5.26 \\
\hline 26 & OK Bullet & 5.38 \\
\hline 27 & CO050322 & 6.89 \\
\hline 28 & Tiger & 7.41 \\
\hline 29 & Ripper & 8.32 \\
\hline 30 & $\mathrm{~T}-136$ & 9.14 \\
\hline 31 & Infinity CL & 9.75 \\
\hline 32 & GA991209-6E33 & 10.21 \\
\hline 33 & CO050303-2 & 10.90 \\
\hline 34 & T154 & 11.16 \\
\hline 35 & Keota & 11.87 \\
\hline 36 & Truman & 11.88 \\
\hline 37 & $25 \mathrm{R} 47$ & 12.13 \\
\hline 38 & Endurance & 13.02 \\
\hline 39 & $25 \mathrm{R} 78$ & 13.24 \\
\hline \multirow[t]{2}{*}{40} & Millenium & 13.25 \\
\hline & & (continued on next page) \\
\hline
\end{tabular}

${ }^{a}$ Plants were artificially inoculated, held in a controlled environment chamber, and assessed after 14 days.

b Percent spikelets affected by blast. 
selves and with those obtained with isolate T-25. Evidence of the presence of physiological races among these isolates, as well as the level of statistical interaction between cultivars and isolates, were also considered. A standard set of differential cultivars has not been established for race identification of the Triticum pathotype of $M$. oryzae (23). However, a set of red winter wheat cultivars (Jagalene, Overley, Santa Fe, JackPot, Fuller, and Everest) that showed a continuum of reaction to blast isolate T-25 was used. All of these $M$. oryzae isolates were originally collected in 1988 in the Paraná State of Brazil from different wheat varieties (IAPAR 17, Anahuac, Anahuac, and Tapejara, respectively) and at different locations (Cianorte, Floresta, Pallaro Farm, and São Jorge de Ivaí, respectively).

Data analysis. The Pearson's correlation coefficient was used to measure the strength of association (reproducibility) between two independent wheat blast phenotyping experiments. The highly susceptible cultivar Everest, which was included as a susceptible control in all experiments, was analyzed alone in order to determine the consistency of its reaction over experiments. Analyses of variance of the percentage of wheat spikelets affected by wheat blast were determined using PROC GLM in SAS 9.2 (SAS Institute, Cary, NC, USA). Values used on head resistance, obtained from a set of 12 cultivars showing a continuum of reaction to wheat blast, were pooled from different experiments. The relationship between seedling resistance and head resistance was determined by linear regression using PROC REG in SAS 9.2.

Table 1. (continued from previous page)

\begin{tabular}{|c|c|c|}
\hline No. & Cultivar & Disease severity \\
\hline 41 & WB-Cedar & 13.83 \\
\hline 42 & HV9W96-1383R & 14.16 \\
\hline 43 & Tomahawk & 14.26 \\
\hline 44 & $25 \mathrm{R} 62$ & 16.79 \\
\hline 45 & McGill & 16.87 \\
\hline 46 & TAM 111 & 16.89 \\
\hline 47 & Fuller & 17.46 \\
\hline 48 & Robidoux & 19.32 \\
\hline 49 & HV9W03-696R-2 & 21.33 \\
\hline 50 & Centerfield & 24.83 \\
\hline 51 & Camelot & 25.57 \\
\hline 52 & Heyne & 26.80 \\
\hline 53 & $\mathrm{CO} 050270$ & 27.93 \\
\hline 54 & Settler CL & 29.05 \\
\hline 55 & 9553 & 31.44 \\
\hline 56 & TAM 304 & 31.55 \\
\hline 57 & TAM 107 & 31.93 \\
\hline 58 & 2525 & 32.67 \\
\hline 59 & $\mathrm{~T}-151$ & 35.55 \\
\hline 60 & Triumph 64 & 35.80 \\
\hline 61 & Aspen & 37.42 \\
\hline 62 & CO06052 & 37.86 \\
\hline 63 & $\mathrm{~T}-140$ & 39.02 \\
\hline 64 & Hitch & 40.82 \\
\hline 65 & TAM 105 & 41.18 \\
\hline 66 & Armour & 42.94 \\
\hline 67 & CO04499 & 44.34 \\
\hline 68 & $\mathrm{~T}-81$ & 45.73 \\
\hline 69 & Above CL & 47.15 \\
\hline 70 & Hondo & 47.81 \\
\hline 71 & CO06424 & 50.00 \\
\hline 72 & CO04393 & 57.00 \\
\hline 73 & Billings & 58.29 \\
\hline 74 & Duster & 58.67 \\
\hline 75 & Ike & 58.75 \\
\hline 76 & CO050233-2 & 62.67 \\
\hline 77 & KS04WGRC46 & 68.67 \\
\hline 78 & Oakes & 69.48 \\
\hline 79 & 2137 & 71.29 \\
\hline 80 & BO30543 & 73.24 \\
\hline 81 & KS970093 & 90.33 \\
\hline 82 & Winterhawk & 94.23 \\
\hline 83 & Karl 92 & 94.52 \\
\hline 84 & Wesley & 95.00 \\
\hline 85 & Everest & 95.10 \\
\hline
\end{tabular}

\section{Results}

There was a highly significant positive correlation $(P<0.0001)$ between the two independent experiments aimed to determine the reproducibility of disease phenotyping on adult plants. The Pearson's correlation coefficient indicated that the strength of association between these experiments was very high $(r=0.96)$. About $93 \%$ of the reaction in experiment 2 was explained by the reaction in experiment 1 (Fig. 1).

To quantify the variability due to random effects across experiments, cultivar Everest was used as a susceptible control in all experiments. Analyzed alone, Everest was not significantly different $(P>0.05)$ for wheat blast infection in any of the phenotyping experiments; therefore, disease severity data were pooled accordingly across experiments. To date, a total of 85 cultivars have been tested for susceptibility to wheat blast at least one time, but many were tested more than once. Disease severity values fell into a continuum from highly susceptible to highly resistant cultivars to the single Brazilian isolate T-25 (Table 1). This continuum (Table 1) consisted of 80 cultivars with less than $75 \%$ disease severity and 5 cultivars with ratings greater than $75 \%$ disease severity. Among entries tested at least twice, cultivars Everest and Karl 92 were classified as highly susceptible with more than $90 \%$ disease severity, and cultivars Postrock, JackPot, Overley, Jagalene, Jagger, and Santa Fe were classified as resistant and showed less than 3\% infection.

There was a significant positive linear relationship $(P<0.05)$ between seedling and head resistance (Fig. 2). The estimated linear regression slope was $1.6 \%$ disease severity. The value for the coefficient of determination $\left(R^{2}\right)$ indicates that seedling infection explained $57 \%$ of the variation in head infection. At the seedling stage, cultivars JackPot, Jagalene, Postrock, Santa Fe, Aspen, and TAM107 were placed in the resistant category; Tomahawk, Armour, Hitch, and Fuller were moderately resistant; and Karl 92 and Everest were moderately susceptible. At the head stage, cultivars JackPot, Jagalene, Postrock, and Santa Fe were placed into the resistant category; Tomahawk and Fuller were moderately resistant; TAM107, Aspen, Hitch, and Armour were moderately susceptible; whereas cultivars Karl 92 and Everest were in the susceptible category with at least $95 \%$ disease severity. Six of the 12 cultivars were scored with the same disease phenotype on both seedling leaves and heads, while six showed variation.

When comparing the disease phenotypes for isolates T-7, T-12, $\mathrm{T}-22$, and T-25 on six cultivars, analysis of variance showed that there were significant $(P<0.0001)$ differences among cultivars, and among pathogen isolates $(P<0.05)$. Cultivars Jagalene, Overley, Santa Fe, and Jackpot showed high levels of resistance to all

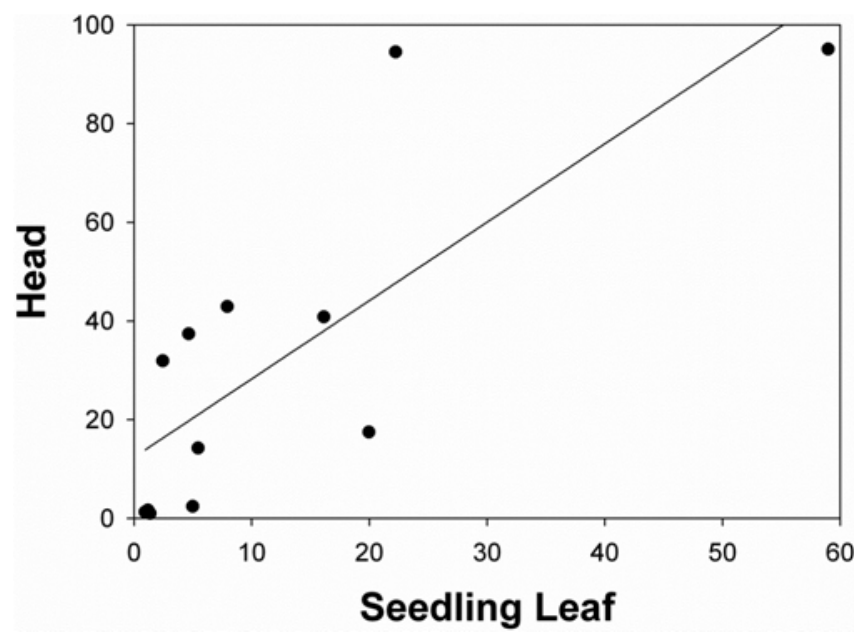

Fig. 2. Linear regression analysis between percent tissue affected by blast on wheat seedling leaves versus wheat heads. Relationship between leaf severity (LS) and head severity (HS) was: $\mathrm{HS}=12.39+1.59^{*} \mathrm{LS}, N=12, R^{2}=0.57, P=0.0026$. 
isolates, while Fuller was moderately resistant and Everest was highly susceptible to all isolates. A significant isolate-by-cultivar interaction was observed $(P<0.0001)$.

\section{Discussion}

Variation in the reaction of cultivars to artificial inoculations can occur over time among experiments. This variation can be accounted for in terms of random effects that can also affect the reproducibility of experiments. Random-effects differences can occur as a result of the vigor of the pathogen inoculum, inoculation technique, environmental conditions, and consistency of disease assessments over time. Based on our results, no significant differences in the reaction of the highly susceptible cultivar Everest to isolate T-25 were observed across experiments. Therefore, the variability from these random effects was minimal and results presented here are assumed to be reasonably accurate. In addition, our correlation analyses showed that disease-rating correlations between repetitions were extremely high between independent experiments (Fig. 1). As a result, high levels of reproducibility were present in these phenotyping experiments.

There was a positive correlation between the disease phenotypes obtained with seedling and head inoculations (Fig. 2). The two most susceptible cultivars at the head stage, Karl 92 and Everest, showed the highest levels of severity at the seedling stage. Additionally, there was no evidence for the presence of susceptible cultivars at the seedling stage that showed resistance at the head stage. These results are concordant with observations of Arruda et al. (1). All cultivars that were resistant at the head stage (JackPot, Jagalene, Postrock, and Santa Fe) were also resistant at the seedling stage. However, two resistant cultivars at the seedling stage, Aspen and TAM107, were moderately susceptible at the head stage. Leaf resistance in the seedling stage is not a good predictor of head resistance in mature plants. Thus, relying on disease phenotypes from seedlings could lead to incorrectly identifying wheat genotypes as resistant when they are susceptible. In addition, because wheat blast in the field is primarily a head disease, phenotyping at the head stage is more relevant than at the seedling stage to accurately identify resistance. These findings are important to consider while testing cultivars under artificial epidemic conditions and before releasing lines as resources of resistance. Zhuang et al. (25) provided evidence that, in rice, there is a genetic basis for the difference in response to leaf and neck blast resistance. In their study, they concluded that different blast resistance genes might be effective at different developmental stages. It remains to be determined whether the reaction of wheat at the leaf and head stages is under separate genetic control.

Although there was a significant $(P<0.0001)$ cultivar-by-isolate interaction, there was no evidence for the presence of physiological

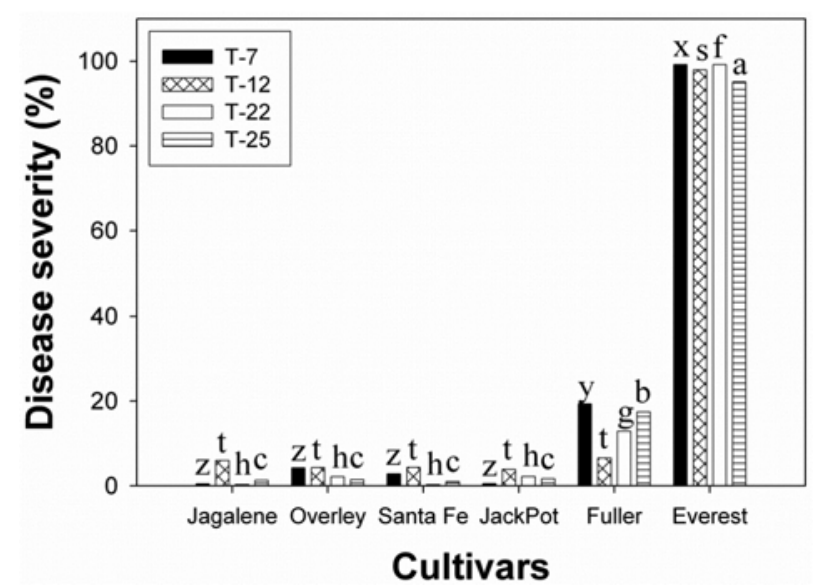

Fig. 3. Reaction of six selected wheat cultivars to four isolates (T-7, T-12, T-22, T-25) of the Triticum pathotype of Magnaporthe oryzae. Values within an isolate, when followed by a common letter, are not significantly different according to ANOVA followed by Fisher's protected LSD $(P=0.05)$. races among isolates T-7, T-12, T22, and T-25 (Fig. 3). Disease phenotypes across cultivars were not isolate specific. The significant interaction was due to small quantitative differences among isolates on certain cultivars. For the purpose of this study, those small differences were deemed of little practical importance. For example, when inoculated with isolate T-12, there was no statistical difference in disease ratings for cultivars Fuller and JackPot; however, when inoculated with isolates T-7, T-22, and T-25, disease ratings for Fuller were statistically higher than those for JackPot. Small variations such as this among cultivars in their individual reaction to different isolates resulted in a significant isolate-bycultivar interaction. Minor variations among isolates in phenotypes for intermediate cultivars such as Fuller are often observed for other pathogens (W. W. Bockus, unpublished). However, the overall resistance of this cultivar relative to susceptible Everest was expressed after inoculations with all four isolates. In conclusion, in no case did a cultivar display high levels of resistance to one isolate and high levels of susceptibility to another isolate or vice versa.

Cultivars Postrock, JackPot, Overley, Jagalene, Jagger, and Santa Fe showed high levels of resistance to the four isolates used in these experiments. However, it is important to determine whether resistance in these cultivars is manifested when tested against more recent isolates as well as under natural epidemic conditions. This is especially important because high levels of virulence diversity have been reported in recent Brazilian wheat blast populations (20). Studies $(22,23)$ suggest that many physiological races are present in South America 14 years after the emergence of this disease (14). It is unknown if the recent wheat blast populations in South America differ in virulence or aggressiveness compared with the isolates associated with the original epidemics; the four isolates we had available for these experiments were collected in Brazil soon after the emergence of wheat blast in 1988. Consequently, the U.S. cultivars identified as resistant in this study need to be tested with recently collected isolates and validated under natural epidemic conditions. Nevertheless, this is the first report of the reaction of U.S. winter wheat cultivars to the Triticum pathotype of M. oryzae. The data reported here should be of value to the development of mitigation strategies in anticipation of the possible introduction of wheat blast into the United States.

\section{Acknowledgments}

This project was funded by an Agriculture and Food Research Initiative Competitive Grant (No. 2009-55605-05201) from the USDA National Institute of Food and Agriculture. Contribution number 12-218-J from the Kansas Agricultural Experiment Station.

\section{Disclaimer}

The U.S. Department of Agriculture (USDA) prohibits discrimination in all its programs and activities on the basis of race, color, national origin, age, disability, and where applicable, sex, marital status, familial status, parental status, religion, sexual orientation, genetic information, political beliefs, reprisal, or because all or part of an individual's income is derived from any public assistance program. (Not all prohibited bases apply to all programs.) Persons with disabilities who require alternative means for communication of program information (Braille, large print, audiotape, etc.) should contact USDA's TARGET Center at (202) 720-2600 (voice and TDD). To file a complaint of discrimination, write to USDA, Director, Office of Civil Rights, 1400 Independence Avenue, S.W., Washington, D.C. 20250-9410, or call (800) 795-3272 (voice) or (202) 720-6382 (TDD). USDA is an equal opportunity provider and employer. Mention of trade names or commercial products in this publication is solely for the purpose of providing specific information and does not imply recommendation or endorsement by the U.S. Department of Agriculture.

\section{Literature Cited}

1. Arruda, M., Bueno, C., Zamprogno, K., Lavorenti, N., and Urashima, A. 2005. Reação do trigo à Magnaporthe grisea nos diferentes estádios de desenvolvimento. Fitopatol. Bras. 30:121-126.

2. Barea, G., and Toledo, J. 1996. Identificación y zonificación de Pyricularia o brusone (Pyricularia oryzae) en el cutivo de trigo en el departamento de Santa Cruz. Pages 76-86 in: Centro de Investigación Agrícola Tropical. Informe Tecnico. Proyecto de Investigacion Trigo. Santa Cruz de la Sierra, Bolivia.

3. Busso, C., Nobuyoshi E., Franco, F., and Avezum, M. 2007. Genetic and 
molecular characterization of pathogenic isolates of Pyricularia grisea from wheat (Triticum aestivum Lam.) and triticale ( $\times$ Triticosecale Wittmack) in the state of Paraná, Brazil. Rev. Iberoam Micol. 24:167-170.

4. Cabrera, M., and Gutiérrez, S. 2007. Primer registro de Pyricularia grisea en cultivos de trigo del NE de Argentina. Depto. Protección Vegetal, Facultad de Ciencias Agrarias, UNNE. Available online at: agr.unne.edu.ar/ Extension/Res2007/SanVegetal/SanVegetal_06.pdf

5. Couch, B., Fudal, I., Lebrun, M., Tharreau, D., Valent, B., Van Kim, P., Nottéghem, J., and Kohn, L. 2005. Origins of host-specific populations of the blast pathogen Magnaporthe oryzae in crop domestication with subsequent expansion of pandemic clones on rice and weeds of rice. Genetics 170:613-630.

6. Cruz, M., Prestes, A., Maciel, J., and Scheeren, P. 2010. Resistencia parcial à brusone de genótipos de trigo comum e sintético nos estádios de planta jovem e de planta adulta. Trop. Plant Pathol. 35:1:24-31.

7. Dos Anjos, J., Da Silva, D., Charchar, M., and Rodrigues, G. 1996. Ocorrência de brusone (Pyricularia grisea) em trigo e centeio na região dos cerrados do Brasil Central. Pesquisa Agropecuaria Bras. 31:79-82.

8. Goulart, A. 2005. Perdas em trigo causadas pela brusone. Pages 123-130 in: Workshop de Epidemiologia de Doenças de Plantas. Viçosa, M. Quantificação de perdas no manejo de doenças de plantas: anais. Viçosa, M: Universidade Federal de Viçosa, 2004b.

9. Goulart, A., and Paiva, F. 1992. Incidência da brusone (Pyricularia oryzae) em diferentes cultivares de trigo (Triticum aestivum) em condições de campo. Fitopatol. Bras. 17:321-325.

10. Goulart, A., and Paiva, F. 2000. Perdas no rendimiento de grãos de trigo causada por Pyricularia grisea, nos anos de 1991 e 1992, no Mato Grosso do Sul. Sum. Phytopathol. 26:279-282.

11. Goulart, A., Paiva, F., and Mesquita, A. 1990. Ocorrência da brusone (Pyricularia oryzae) do trigo (Triticum aestivum) em Matto Grosso do Sul. Fitopatol. Bras. 15:112-114.

12. Goulart, A., Paiva, F., and Mesquita, N. 1992. Perdas en trigo (Triticum aestivum) causadas por Pyricularia oryzae. Fitopatol. Bras. 17:115-117.

13. Igarashi, S. 1990. Update on wheat blast (Pyricularia oryzae) in Brazil. Pages 480-483 in: Proc. Int. Conf.-Wheat Nontraditional Warm Areas. D. Saunders, ed. Mexico, D.F.

14. Igarashi, S., Utimada, C., Igarashi, L., Kazuma, A., and Lopes, R. 1986.
Pyricularia sp. em trigo. I. Ocorrência de Pyricularia sp. no Estado do Paranà. Fitopatol. Bras. 11:351-352.

15. Kohli, M., Mehta, Y., Guzman, E., Viedma, L., and Cubilla, L. 2011. Pyricularia blast - A threat to wheat cultivation. Czech J. Genet. Plant Breed. 47:S130-134.

16. McMullen, M., Jones, R., and Gallenberg, D. 1997. Scab of wheat and barley: A re-emerging disease of devastating impact. Plant Dis. 81:12:13401348 .

17. Picinini, E., and Fernandes, J. 1990. Ocorrência da brusone (Pyricularia oryzae) em lavouras comerciais de trigo (Triticum aestuvum) no Estado do Rio Grande do Sul. Fitopatol. Bras. 15:83-84.

18. Prestes, A., Arendt, P., Fernandes, M., and Scheeren, P. 2007. Resistance to Magnaporthe grisea among Brazilian wheat genotypes. Pages 119-133 in: Wheat Production in Stressed Environments. Back et al., eds. Springer.

19. Urashima, A., Grosso, C., Stabili, A., Freitas, E., Silva, D., Netto, D. Franco, I., and Merola Bottan, J. 2009. Effect of Magnaporthe grisea on seed germination, yield and quality of wheat. Page 267 in: Advances in Genetic, Genomics and Control of Rice Blast Disease. G. Wang and B. Valent, eds. Springer, Netherlands.

20. Urashima, A., Hashimoto, Y., Don, L., Kusaba, M., Tosa, Y., Nakayashiki, H., and Mayama, S. 1999. Molecular analysis of the wheat blast population in Brazil with a homologue of retrotransposon MGR583. Ann. Phytopathol Soc. Jpn. 65:429-436.

21. Urashima, A., Igarashi, S., and Kato, H. 1993. Host range, mating type and fertility of Pyricularia grisea from wheat in Brazil. Plant Dis. 77:12111216

22. Urashima, A., and Kato, H. 1994. Varietal Resistance and Chemical Control of Wheat Blast Fungus. Sum. Phytopathol. 20:107-112.

23. Urashima, A., Lavorenti, N., Goulart, A., and Mehta, Y. 2004. Resistance spectra of wheat cultivars and virulence diversity of Magnaporthe grisea isolates in Brazil. Fitopatol. Bras. 29:511-518.

24. Viedma, L. 2005. Wheat blast occurrence in Paraguay. Phytopathology (Abstr.) 95:S152.

25. Zhuang, J., Ma, W., Wu, J., Chai, R., Lu, J., Fan, Y., Jin, M., Leung, H., and Zheng, K. 2002. Mapping of leaf and neck blast resistance genes with resistance gene analog, RAPD and RFLP in rice. Euphytica 128:363-370. 